\title{
An evaluation of total lysine as a predictor of lysine status in protein concentrates for growing pigs
}

\author{
By E. S. BATTERHAM, R. D. MURISON AND C. E. LEWIS \\ NSW Department of Agriculture, Agricultural Research Centre, \\ Wollongbar, New South Wales 2480, Australia
}

(Received I 2 July I977 - Accepted 6 January 1978)

\begin{abstract}
1. Eight protein concentrates were compared on a total lysine basis in lysine-deficient diets for pigs during the $20-45 \mathrm{~kg}$ growth phase. Each diet was also supplemented with free lysine to verify that lysine was the first limiting amino acid.

2. With fish meal, skim-milk powder, rapeseed meal and soya-bean meal growth rates and feed conversion efficiencies were similar and superior $(P<0.05)$ to those produced with cottonseed meal, two meat meals and sunflower meal.

3. The response to added free lysine confirmed that lysine was the first limiting amino acid in all diets except skim milk, where the growth response was not significant $(P<0.05)$.

4. The growth response of the pigs indicated that the availability of lysine in cottonseed meal, the two meat meals and sunfiower meal was reduced by approximately $60 \%$ compared to that in the other protein concentrates.

5. Rat bio-assay estimates of the availability of lysine in the protein concentrates were in general agreement with those calculated from the response of pigs. There was little relationship between the Silcock estimates for lysine availability for the cottonseed, meat meals or sunflower meal relative to either the rat bio-assay estimates or the response of pigs.
\end{abstract}

Lysine is normally the first limiting amino acid in cereal-based diets for growing pigs (Braude, Mitchell, Myres, Newport \& Cuthbertson, 1972). This limitation is usually overcome by the inclusion of protein concentrates. The availability of lysine in these concentrates may be reduced if severe heat is used during processing. Consequently, techniques for estimating lysine availability have been developed. The most widely adopted of these are based on reactions with the free $\epsilon$-amino group of lysine (e.g. Carpenter, I960; Roach, Sanderson \& Williams, 1967).

Recent indications are that lysine availability is largely unaffected when modern processing procedures are properly applied. For example, Milner \& Westgarth (1973) reported values of $0.93-0.97$ for availability of lysine in a selection of protein concentrates. Taverner \& Rayner (I975) also reported values from $0.8 \mathrm{I}$ to $0.9 \mathrm{I}$ for available lysine in vegetable proteins processed by either expeller or solvent extraction; in subsequent pig experiments, both total and available lysine values were closely correlated with pig performance. Thus, if lysine availability is relatively unaffected during processing, then total lysine values are the most convenient method for formulating diets. In the work reported here, total lysine was evaluated as a predictor of the lysine status of a range of protein concentrates.

\section{EXPERIMENTAL}

\section{Pig diets}

Diets were formulated to contain $6 \cdot \mathrm{I} g$ lysine $/ \mathrm{kg}$, with the protein concentrates contributing $3 \mathrm{~g} / \mathrm{kg}$ and wheat $3 . \mathrm{I} \mathrm{g} / \mathrm{kg}$ (Table I). These diets contained approximately $75 \%$ of the estimated requirements of pigs for lysine (Agricultural Research Council, 1967). The cottonseed, rapeseed and sunflower meals were 'prepress' solvent-extracted; the soya-bean meal was solvent-extracted; the skim-milk powder was spray-dried and the fish meal and 
Table I. Composition $(\mathrm{g} / \mathrm{kg})$ of the diets* fed to pigs

Ingredients
Wheat
Cottonseed meal
Fish meal
Meat meal r
Meat meal 2
Rapeseed meal
Skim milk
Soya-bean meal
Sunflower meal
Minerals and vitamins $\dagger$
Boneflour
FeSO
Tallow $7 \mathrm{H}_{2} \mathrm{O}$
Wheat starch

\begin{tabular}{|c|c|c|c|c|c|c|c|}
\hline \multicolumn{8}{|c|}{ Diet } \\
\hline I & 2 & 3 & 4 & 5 & 6 & 7 & 8 \\
\hline 760 & 760 & 760 & 760 & 760 & 760 & 760 & 760 \\
\hline 167 & - & - & - & - & - & - & - \\
\hline- & 52 & - & - & - & - & - & - \\
\hline - & - & 107 & - & - & - & - & - \\
\hline- & - & - & 107 & - & - & - & - \\
\hline- & - & - & - & I 58 & - & - & - \\
\hline- & - & - & - & - & 115 & - & - \\
\hline- & - & - & - & - & - & 115 & - \\
\hline - & - & - & - & - & - & - & 176 \\
\hline 5 & 5 & 5 & 5 & 5 & 5 & 5 & 5 \\
\hline 25 & 25 & - & - & 25 & 25 & 25 & 25 \\
\hline 2 & - & - & - & - & 一 & - & 一 \\
\hline 36 & - & 12 & 3 & 31 & - & 12 & 25 \\
\hline 5 & I 58 & 116 & I 25 & 21 & 95 & 83 & 9 \\
\hline
\end{tabular}

* Diets nos 9-1 6 had the same composition as diets nos I-8 respectively, except each diet was supplemented with $4 \mathrm{~g} \mathrm{~L}$-lysine at the expense of wheat starch.

$\dagger$ Contributed (/kg diet) iron $60 \mathrm{mg}$, zinc $100 \mathrm{mg}$, manganese $30 \mathrm{mg}$, copper $5 \mathrm{mg}$, iodine $2 \mathrm{mg}$, selenium $0.15 \mathrm{mg}$, sodium chloride $2.5 \mathrm{~g}$, retinol equivalent $960 \mu \mathrm{g}$, cholecalciferol $12 \mu \mathrm{g}, \alpha$-tocopherol $20 \mathrm{mg}$, thiamin I $\mathrm{mg}$, riboflavin $3 \mathrm{mg}$, nicotinic acid $12 \mathrm{mg}$, pantothenic acid $10 \mathrm{mg}$, pyridoxine $1.5 \mathrm{mg}$, cyanocobalamin I 5 ug, pteroylmonoglutamic acid $2 \mathrm{mg}$, choline $500 \mathrm{mg}$, ascorbic acid Io $\mathrm{mg}$, biotin $0.1 \mathrm{mg}$, oxytetracycline hydrochloride $10 \mathrm{mg}$.

Table 2. Chemical composition $(\mathrm{g} / \mathrm{kg})$ of the diets* fed to pigs

\begin{tabular}{|c|c|c|c|c|c|c|c|c|}
\hline & \multicolumn{8}{|c|}{ Diet } \\
\hline & $\underset{\mathrm{I}}{\text { Cotton }}$ & $\begin{array}{c}\text { Fish } \\
2\end{array}$ & $\begin{array}{c}\text { Meat I } \\
3\end{array}$ & $\begin{array}{c}\text { Meat } 2 \\
4\end{array}$ & $\underset{5}{\text { Rape }}$ & $\begin{array}{c}\text { Skim milk } \\
6\end{array}$ & $\begin{array}{c}\text { Soya } \\
7\end{array}$ & $\begin{array}{c}\text { Sunflower } \\
8\end{array}$ \\
\hline $\begin{array}{l}\text { Crude protein } \dagger \\
(\text { nitrogen } \times 6 \cdot 25)\end{array}$ & 177 & 149 & 166 & I65 & I 67 & 152 & 164 & 183 \\
\hline Dry matter & 879 & 897 & 887 & 890 & 893 & 878 & 895 & $89 \mathrm{I}$ \\
\hline Essential amino acids & & & & & & & & \\
\hline Threonine & $5 \cdot 3$ & $4 \cdot 8$ & $5 \cdot 1$ & $5 \cdot 0$ & $5 \cdot 4$ & $5 \cdot I$ & $5 \cdot 4$ & 5.9 \\
\hline Valine & $7 \cdot 8$ & 6.9 & $7 \cdot 4$ & $7 \cdot 1$ & $7 \cdot 5$ & $7 \cdot 5$ & $7 \cdot I$ & $8 \cdot 2$ \\
\hline Methionine + cystine & $5 \cdot 2$ & $2 \cdot I$ & $4 \cdot 8$ & 5.0 & $5 \cdot 6$ & $5 \cdot 0$ & $4 \cdot 9$ & $6 \cdot 0$ \\
\hline Isoleucine & $6 \cdot 3$ & 6.0 & $6 \cdot 2$ & 6.0 & $6 \cdot 4$ & 6.2 & $6 \cdot 3$ & $7 \cdot 1$ \\
\hline Leucine & 10.9 & $11 \cdot 0$ & $11 \cdot 6$ & II. 5 & II. 5 & $11 \cdot 5$ & II $\cdot 2$ & $12 \cdot 1$ \\
\hline $\begin{array}{l}\text { Phenylalanine + tyrosine } \\
\text { Lysine }\end{array}$ & $\begin{array}{r}\mathrm{I} 4 \cdot 8 \\
6 \cdot 1\end{array}$ & $\begin{array}{r}13.5 \\
6.1\end{array}$ & $\begin{array}{r}13 \cdot 6 \\
6 \cdot 1\end{array}$ & $\begin{array}{r}13 \cdot 3 \\
6 \cdot 1\end{array}$ & $\begin{array}{r}13 \cdot 8 \\
6 \cdot 1\end{array}$ & $\begin{array}{r}13 \cdot 3 \\
6 \cdot 1\end{array}$ & $\begin{array}{r}14 \cdot 3 \\
6 \cdot 1\end{array}$ & $\begin{array}{r}15.1 \\
6.1\end{array}$ \\
\hline $\begin{array}{l}\text { Histidine } \\
\text { Arginine }\end{array}$ & $\begin{array}{r}4 \cdot 5 \\
12 \cdot 7\end{array}$ & $\begin{array}{l}3 \cdot 8 \\
8 \cdot 3\end{array}$ & $\begin{array}{r}3 \cdot 9 \\
10 \cdot 1\end{array}$ & $\begin{array}{l}3 \cdot 8 \\
9 \cdot 8\end{array}$ & $\begin{array}{l}4 \cdot 3 \\
9 \cdot 6\end{array}$ & $\begin{array}{l}3 \cdot 7 \\
7 \cdot 2\end{array}$ & $\begin{array}{r}4 \cdot 0 \\
1 I \cdot 6\end{array}$ & $\begin{array}{r}4 \cdot 5 \\
12 \cdot 2\end{array}$ \\
\hline
\end{tabular}

* Diets nos 9-16 contained $10 \cdot \mathrm{I} \mathrm{g}$ lysine $/ \mathrm{kg}$; for details of composition, see Table $\mathrm{I}$.

$\dagger$ Crude protein contents of the components were $(\mathrm{g} / \mathrm{kg})$ : wheat 148 , cottonseed meal 389 , fish meal 710 , meat meal I 504, meat meal 2494, rapeseed meal 348, skim-milk powder 352 , soya-bean meal 452 , sunflower meal 403.

meat meals were dry-rendered. All meals were produced in Australia. Dietary crude protein (nitrogen $\times 6.25$ ) varied from 149 to $183 \mathrm{~g} / \mathrm{kg}$ as a result of the constant contribution of lysine from each protein concentrate (Table 2 ), but this variation was considered unlikely to affect the response of the pigs as the essential amino acid content of diets nos I-8 was similar. The cottonseed meal contained $300 \mathrm{mg}$ free gossypol $/ \mathrm{kg}$ and ferrous sulphate was added to inactivate any effects it may have (Husby \& Kroening, 1971). Dietary energy 
content was adjusted to $14.6 \mathrm{MJ}$ digestible energy $/ \mathrm{kg}$ using wheat starch and tallow as non-protein energy sources. Diets nos 9-16 had the same composition as for diets nos $1-8$, except each was supplemented with $4 \mathrm{~g}$ L-lysine (as L-lysine monohydrochloride, anhydrous)/ $\mathrm{kg}$ to verify that lysine was the first limiting amino acid.

The dietary components were analysed for crude protein using a macro-Kjeldahl method with selenium as the catalyst; total amino acids using reflux hydrolysis under nitrogen with $6 \mathrm{M}$-hydrochloric acid and separation of the amino acids by ion-exchange chromatography with a Technicon amino acid analyser, and Silcock available lysines according to Roach et al. (1967). Digestible energy in the diets was calculated using literature values and results of previous determinations at this Agricultural Research Centre.

\section{Animals and procedure}

The sixteen diets were arranged in a randomized block design with eight pigs allotted per diet. Four were females and four were castrate males, all of Large White breed. The pigs were penned individually and water supplied by 'nipple' drinkers. Dietary treatments were introduced when the pigs reached $20 \mathrm{~kg}$ live weight.

The diets were offered at a daily rate of $1000 \mathrm{~g}$ at $20 \mathrm{~kg}$ live weight, with $100 \mathrm{~g}$ increments $/ 2.5 \mathrm{~kg}$ live-weight gain. The pigs were fed six times daily, at intervals of $3 \mathrm{~h}$, to enhance the utilization of the added free lysine (Batterham, 1974). The feed was offered dry. Rations were adjusted after the weekly weighings of the pigs.

The pigs were slaughtered after reaching a minimum weight of $45 \mathrm{~kg}$. The carcasses were chilled overnight and cold carcass weight recorded. The ham was dissected and the lean content used as an indicator of carcass leanness. Pig response was assessed in terms of daily live-weight gain, feed conversion ratio ( $\mathrm{kg}$ feed eaten $/ \mathrm{kg}$ live-weight gain), dressing percentage (cold carcass weight as a percentage of live weight) and lean content in the ham. The results were analysed by analysis of variance and treatment means separated by least significant difference.

\section{Rat bio-assay}

The composition of the basal diet $(\mathrm{g} / \mathrm{kg}$ ) was wheat 650 , wheat gluten 100 , maize oil 20 , boneflour 25, minerals and vitamins 5 (composition as in Table $\mathrm{I}$ ) and wheat starch 200 . Three levels of standard lysine $\left(0.75, \mathrm{I}^{\circ} 5\right.$ and $\left.2 \cdot 25 \mathrm{~g} / \mathrm{kg}\right)$ were used to determine the response to lysine. The protein concentrates were incorporated into the diets to supply the same three levels of total lysine as used to determine the standard lysine response. This was done at the expense of wheat starch. Additional maize oil was used with some protein concentrates to maintain the estimated digestible energy content of the diets.

Two female and two male albino rats, approximately $26-28 \mathrm{~d}$ old, were used per dose. The rats were individually caged in a room where the temperature and relative humidity were maintained at $21^{\circ} \pm I^{\circ}$ and $50 \pm 5 \%$ respectively. Lighting was supplied for $12 \mathrm{~h}$ daily. Food was supplied in self feeders. The rats were assessed for weight gain and feed conversion efficiency (FCE) ( $\mathrm{g}$ gain/g food eaten) over a I $4 \mathrm{~d}$ test.

Single assays were used for sunflower, cottonseed and fish meal. Double assays were used for meat meal I and skim milk and meat meal 2 and soya-bean meal. The results were analysed by the slope-ratio technique of Finney (1964). The potencies and their standard deviations were calculated.

\section{RESULTS}

Growth rates and teed conversion efficiencies of pigs given fish meal, rapeseed meal, skim milk and soya-bean meal were similar and superior $(P<0.05)$ to those given cottonseed meal, the meat meals and sunflower meal (Table 3). The lean content of the hams was 
Table 3. Response of pigs during the 20-45 $\mathrm{kg}$ growth phase to diets containing different protein concentrates (diets nos I-8) and supplemented with free lysine (diets nos 9-16)

\begin{tabular}{|c|c|c|c|c|}
\hline Diet $\uparrow$ & Test protein & $\begin{array}{l}\text { Live-wt gain } \\
\quad(\mathrm{g} / \mathrm{d})\end{array}$ & $\begin{array}{c}\text { Feed conversion } \\
\text { ratio } \\
(\mathrm{kg} \text { feed eaten } / \mathrm{kg}) \\
\text { live-wt gain) }\end{array}$ & $\begin{array}{c}\text { Lean in ham } \\
(\mathrm{g} / \mathrm{kg})\end{array}$ \\
\hline I & Cottonseed & 460 & 2.93 & 602 \\
\hline 2 & Fish & $\$ 17$ & 2.65 & 623 \\
\hline 3 & Meat I & 484 & $2 \cdot 83$ & 609 \\
\hline 4 & Meat 2 & 475 & 2.84 & 601 \\
\hline 5 & Rapeseed & 538 & 2.55 & 618 \\
\hline 6 & Milk & 536 & $2 \cdot 54$ & 626 \\
\hline 7 & Soya bean & 534 & $2 \cdot 55$ & 630 \\
\hline 8 & Sunflower & 468 & 2.90 & 600 \\
\hline 9 & Cottonseed + lysine & 570 & $2 \cdot 39$ & 660 \\
\hline 10 & Fish + lysine & 580 & $2 \cdot 34$ & 662 \\
\hline I I & Meat $\mathrm{I}+$ lysine & 545 & $2 \cdot 45$ & 658 \\
\hline 12 & Meat $2+$ lysine & 569 & $2 \cdot 40$ & 649 \\
\hline 13 & Rapeseed + lysine & 583 & $2 \cdot 33$ & 657 \\
\hline 14 & Milk+lysine & 557 & $2 \cdot 44$ & 661 \\
\hline I5 & Soya bean + lysine & 605 & $2 \cdot 24$ & 672 \\
\hline 16 & Sunflower + lysine & $55 \mathrm{I}$ & $2 \cdot 45$ & 646 \\
\hline \multicolumn{5}{|c|}{ Statistical analyses } \\
\hline & Proteins & ** & ** & ** \\
\hline & Lysine & ** & ** & ** \\
\hline & Proteins $x$ lysine & ** & ** & NS \\
\hline & \multicolumn{4}{|c|}{ Least significant difference $(P=0.05)$} \\
\hline & Protein means & 24 & 0.11 & 19 \\
\hline & 'Body' of table & 30 & 0.14 & - \\
\hline & SEM & 10 & 0.04 & 8 \\
\hline
\end{tabular}

NS, not significant $(P>0.05) ; * * P<0.01$.

$\dagger$ For details of composition, see Tables I and 2.

greater in the pigs given the former four meals but these differences were not statistically significant $(P<0.05)$ from the latter four meals.

The addition of $4 \mathrm{~g}$ lysine $/ \mathrm{kg}$ feed significantly $(P<0.05)$ increased growth rate and feed conversion efficiency in all diets except skim milk, where the responses were not statistically significant. Lean in the ham was significantly increased $(P<0.01)$ in all diets supplemented with free lysine. The addition of lysine also significantly $(P<0.05)$ increased carcass dressing percentage, from 72.8 in pigs given diets nos $1-8$ to 73.5 in pigs given diets nos 9-16.

The availability of lysine in the protein concentrates ranged from 0.97 for skim milk to 0.84 for meat meal 2, according to the Silcock technique (Table 4). Rat bio-assay estimates ranged from $\mathrm{I} \cdot 06$ for skim milk to 0.43 for sunflower meal when gain was the criteria. With FCE as the criteria, lysine availability ranged from I.03 for skim milk to 0.48 for meat meal 2 . No bio-assay estimates were made with rapeseed meal as the rats refused to consume sufficient food to support adequate growth.

\section{DISCUSSION}

The $17 \%$ difference in growth rates of pigs given diets nos $\mathrm{I}$ and 5 (cottonseed and rapeseed meal respectively) indicates substantial differences in the availability of lysine in the protein concentrates. As the test proteins contributed half the dietary lysine, if the response to 
Table 4. Availability of lysine (fraction of total) in the protein concentrates as assessed by the chemical Silcock technique and by the rat bio-assay technique using weight gain and food conversion efficiency (FCE) as the criteria for availability

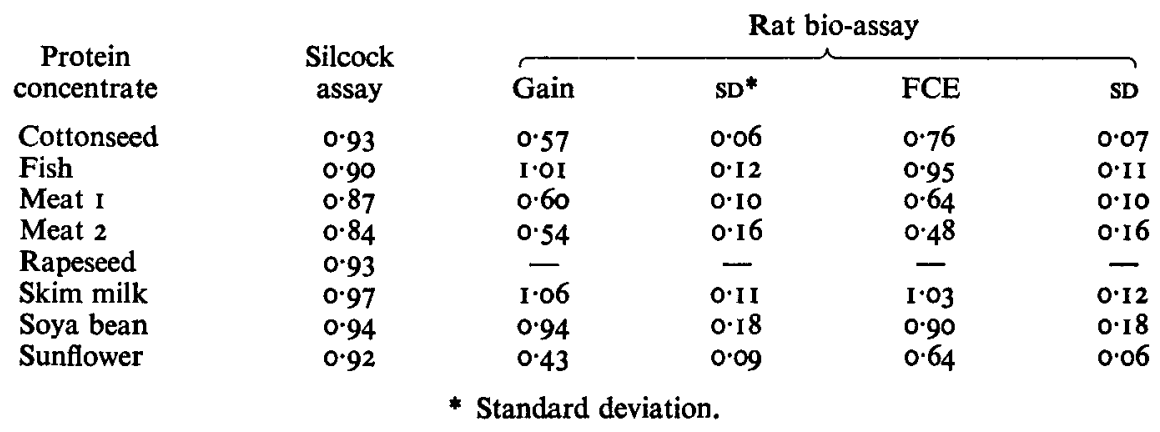

lysine was linear from zero lysine level, then the differences in pig response indicate that the availability of lysine in the rapeseed meal was $34 \%$ greater than in the cottonseed meal. However, it is unlikely that the response to lysine would be linear from the zero level, and the variation in lysine availability could be much greater. For example, in similar experiments conducted at this Agricultural Research Centre, the mean response of pigs in five experiments to supplements of $2 \mathrm{~g}$ lysine/ $\mathrm{kg}$ diet was $77 \mathrm{~g} / \mathrm{d}$ (Batterham \& O'Neill, 1978). In those experiments the basal diets contained between 5.1 and $5.7 \mathrm{~g}$ lysine $/ \mathrm{kg}$ and the growth performance of the pigs (438-548 g live-weight gain/d) was similar to the growth range in the current experiment $(460-538 \mathrm{~g}$ live-weight gain/d). Thus if the potency of $\mathrm{I} g$ lysine $/ \mathrm{kg}$ diet is equivalent to a growth response of $38.5 \mathrm{~g} / \mathrm{d}$, then the differences in performance of pigs given the diets containing cottonseed meal, meat meal I and 2, and sunflower meal compared to the rapeseed meal are equivalent to differences in lysine of approximately $2, \mathrm{I} \cdot 4, \mathrm{I} \cdot 6$ and $\mathrm{I} \cdot 8 \mathrm{~g} / \mathrm{kg}$ diet respectively. As the test proteins contributed $3 \mathrm{~g}$ lysine $/ \mathrm{kg}$ diet, then these differences in lysine availability would be $0.67,0.47,0.53$ and 0.60 respectively, or an average of 0.57 .

The calculations described are based on the assumption that variation in available lysine was the prime factor causing the variation in growth response in the pigs given diets nos I-8. This assumption appears to be valid, as lysine was the major limiting amino acid in all diets except skim milk, where the response to lysine was not statistically significant. In addition, the response to lysine was substantial in pigs given the four diets containing the protein concentrates that produced the least growth (diets nos I, 3, 4 and 8). With the diets containing cottonseed and meat meal 2, the response to lysine eliminated the difference between these diets and the diets containing fish meal, rapeseed meal and skim milk and just failed to do so with the soya-bean meal-containing diet. However, once lysine is given in excess, then other amino acids may become limiting. For this reason, equal growth on all diets supplemented with lysine (diets nos 9-16) would not be expected, or necessary to validate that lysine was the prime limiting factor in diets nos $\mathrm{I}-8$.

Although the protein-energy ratios varied within the diets, it is doubtful that this had any effect on the results. The diets containing cottonseed and sunflower meal had the widest protein-energy ratios and those containing fish meal and skim milk the least. The addition of lysine to these diets had little effect on protein-energy ratios but it eliminated the differences in pig response on these diets. In addition, it is probable that when the available lysine is reduced in a protein concentrate, the availability of the other amino acids will also be reduced, and hence the effective protein concentration in the diet. Thus the 
differences in effective protein-energy ratios in the cottonseed and sunflower meal diets may have been lower than indicated by the crude protein contents.

The rat bio-assay estimates for lysine indicated that the availability of lysine in the cottonseed, meat meals $I$ and 2 and sunflower meal was substantially lower than in the fish, soya bean and skim milk. This was in general agreement with the pig performance results and the calculations of differences in lysine availability in the meals for pigs. There were differences in the rat bio-assay estimates for availability based on gain or FCE within some of the test proteins, and the standard deviation of the potencies was high for some of the assays. Similar differences were reported for a chick assay for methionine by Carpenter, McDonald \& Miller (1972) and appear characteristic of bio-assays.

The Silcock estimates for lysine indicated little difference in the range of availability in the meals and were similar to those reported by Milner \& Westgarth (1973) and Taverner \& Rayner (1975). There was little relationship between the Silcock estimates for cottonseed, meat meals I and 2 and sunflower meal and those for the rat bio-assay or the response of pigs fed on these diets. In view of these differences, it would seem advisable to determine the absolute availability of lysine in the major protein concentrates for pigs and to evaluate the relative efficiency of the different techniques for predicting lysine availability.

The response of pigs to the supplement of free lysine also indicates the potential for lysine in pig feeding. The growth performance of all pigs given the lysine-supplemented diets was excellent. In addition, this increase in growth rate was associated with more efficient feed conversion and a marked improvement in the lean content in the ham. Thus free lysine appears to have considerable application, not only for supplementing poorly balanced proteins (cottonseed and sunflower meals) but also for partially replacing some of the higher-quality meals (fish meal, rapeseed meal and soya-bean meal).

Grateful acknowledgements are made to Messrs N. R. Thompson, A. W. Davis, H. M. Essery and E. R. Layton for management of the pigs and skilled technical assistance; Professor C. G. Payne, University of Sydney, for total amino acid analyses and North West Vegetable Oils Pty Ltd, Narrabri, for the gossypol analysis. This work was supported by financial grants from the Australian Pig Industry Research Committee.

\section{REFERENCES}

Agricultural Research Council (1967). The Nutrient Requirements of Farm Livestock No. 3, Pigs. London: Agricultural Research Council.

Batterham, E. S. (1974). Br. J. Nutr. 31, 237.

Batterham, E. S. \& O'Neill, G. H. (1978). Br. J. Nutr. 39, 259.

Braude, R., Mitchell, K. G., Myres, A. W., Newport, M. J. \& Cuthbertson, A. (I972). Br. J. Nutr. $27,169$. Carpenter, K. J. (1960). Biochem. J. 77, 604.

Carpenter, K. J., McDonald, I. \& Miller, W. S. (1972). Br. J. Nutr. 27, 7.

Finney, D. J. (1964). Statistical Method in Biological Assay 2nd ed. New York: Hafner Publishing Co.

Husby, F. M. \& Kroening, G. H. (1971). J. Anim. Sei. 33, 592.

Milner, C. K. \& Westgarth, D. R. (1973). J. Sci. Fd Agric. 24, 873.

Roach, A. G., Sanderson, P. \& Williams, D. R. (1967). J. Sci. Fd Agric. 18, 274.

Taverner, M. R. \& Rayner, C. J. (1975). Aust. J. exp. Agric. Anim. Husb. 15, 626. 